\title{
Theatricalization of Patriarchate's Power through Television Serials: Legitimation of Rape
}

\author{
Dimitra Laurence Larochelle ${ }^{1}$ \\ ORCID: 000o-0003-2639-2383 • ResearcherID: U-6987-2017 \\ University Sorbonne Nouvelle - Paris 3, UFR Arts et Médias
}

Received 31 October $2017 \cdot$ Revised 20 November $2017 \cdot$ Accepted 25 November 2017

\section{Abstract}

\begin{abstract}
This paper aims to present the results of our empirical research concerning the reception of Turkish television serials in Greece. More precisely, in this paper we tempt to approach the representations projected by the Turkish serial entitled "Futmagul'un suçu ne?" as well as their reception by the public in Greece. The serial in question provides a particular representation of rape: under the cover of a "feminist" ideal (the persecution of the man who raped into a trial) it conveys representations and archetypes that are in accordance with the dominant patriarchal organization and principles; therefore, it contributes to the legitimation of violence against women. Our analysis focuses on the reception of this serial by women in Greece. Our research revealed that the majority of women who were part of the sample, develop through their interpretation various strategies against patriarchate despite the fact that they do not always recognize the archetypical stereotypes projected by the serial in question.
\end{abstract}

Keywords: social representations, cultural studies, serials, gender, violence.

\section{Introduction}

Since 2000, the production of Turkish television serials is in constant development. These serials that have indisputably a great success at a local level are also exported abroad. More precisely, they were first diffused in countries that were in the sphere of cultural influence of the ancient Ottoman Empire (which means the Balkans and the Middle East). Later they were also exported even far, in Latin America, in China, in Pakistan, in India, in Bangladesh etc.

Among these countries, Greece has become a great consumer of Turkish television serials. This consumption has considerably augmented since the economic crisis in Greece. During this period, the local production has been practically diminished. Consequently, Turkish television serials had an ideal context of diffusion, in this country in a state of lack.

The themes of these serials are not original. They remind the practically standardized themes of the classic "soap-operas" or of the "telenovelas" of the Hispanic speaking world of the period $1990-2000$.

The most frequent subjects concern the sentimental relations and more precisely the stories of forbidden love between two persons with different social status or between lovers that are in an ambiguous situation because of a third person that is implicated in the relation.

\footnotetext{
${ }^{1} \mathrm{PhD}$ candidate.
}

(C) Authors. Terms and conditions of Creative Commons Attribution 4.0 International (CC BY 4.0) apply. Correspondence: Dimitra Laurence Larochelle, University Sorbonne Nouvelle - Paris 3, UFR Arts et Médias, 10, rue du Regard 75006, Paris, France. E-mail: larochelle.laurence@gmail.com. 
These serials present different stories that are marked by the rich lifestyle of the protagonists. Protagonists have a lifestyle that is characterized by goods, such as expensive clothes, jewelry, furniture or even cultural goods such as frequent trips etc. So, this lifestyle invites the public to a journey towards fantasy, dream and evasion.

- This paper aims to present the results of our empirical research concerning the reception of the Turkish serial entitled Futmagul'un suçu ne? by the public in Greece.

- Since the beginning of the economic crisis Greece has become a great consumer of Turkish television serials.

- Theatricalization of the patriarchate's power is effectuated by various means, especially by the representation of rape and of rapists.

- The analysis of the reception of these representations by the public showed that women in Greece, even though they consume the cultural product in question, operate resistance against violence towards women.

The values that are conveyed by these serials are identical to those that we find in most of the television serials anywhere in the world (life lasting love, optimism, fight between good and bad etc.). It is about presenting problems that preoccupy every person in its daily life (love problems, survival problems etc.) but always by accompanying these problems by intrigues, passions and rivalries in order to attract the public.

The representation of women through these serials is particular. Women, even those who are represented as dynamic or even emancipated, are often treated as minors and are represented as highly sentimental and therefore very often not capable of taking rational decisions. In addition, they betray men (or other women) frequently by various means. Moreover, violence in general and violence against women in particular is very common to Turkish television programs. So, women in serials are respected by others when they are mothers (or in general when they have a high position in the institution of family) or when they impose their position through the intrigues. Therefore, the analysis of women's position in these serials, as well as its reception by women in Greece is, in our opinion, an important aspect.

2. Presenting the patriarchate values: the case of TV serial

Fatmagul'un sucu ne? and the legitimation of rape

Our research concerns Turkish television serials diffused in Greece. It is actually an analysis of the representations projected by these serials and of the reception of the messages proposed by them by the public in Greece.

More precisely we have conducted a research of 25 interviews between May and August 2016 with people with different socioeconomic backgrounds. These interviews helped us (among other things of course) to establish a list of the Turkish serials that the public in Greece enjoyed watching. Among Greek's most favorite television programs was listed the serial named "Fatmagul'un sucu ne?" which means "what is Fatmagul's fault" ${ }^{2}$. In Greece this serial was simply given the title "Fatmagul".

The story of this serial treats the life of Fatmagul, a young orphan woman leaving with her brother named Rahmi, her sister in law, Mukades, and their child in a village named Ildir in Izmir. Fatmagul, is mistreated daily by Mukades who is jealous of her and consequently hates her but she hopes for a better future with her fiancé, Mustapha who works as a fisherman in order to gather money for their marriage.

\footnotetext{
${ }^{2}$ See Annexes 1 and 2.
} 
In the same village, the Yasaran family (a rich and well-known family of Turkey) is gathered in order to realize the engagement of their son, Selim to the daughter of a politician. At the party of his engagement Selim meets with his cousin Erdogan and his friends Vural and Kerim. So, the three of them (Erdogan, Selim and Vural) are rich (it is a very stereotypical image of rich young men who reside in Istanbul and who are of course spoiled, disrespectful and caring only for their pleasure etc.). On the other hand, Kerim, is their childhood friend who leaves permanently in Ildir and who is poor but beautiful, well-mannered, polite and who had a difficult childhood as his father abandoned his mother who later committed suicide. Therefore, he was raised by Ebe Nine, the mid-wife of the village.

After the engagement party, the four men, having consumed drugs and alcohol, go on a promenade to the beach where they meet accidentally Fatmagul and they rape her successively. Kerim, who was the last in the row to rape the girl could not commit the act of the rape and he was just watching the scene without participating actively. Later, the four men abandoned the woman unconscious.

The next morning Fatmagul was found and was transported to the local hospital. Mustafa, abandoned Fatmagul when he learned what had happened to her and Mukades who found Selim's wedding ring in the scene of the crime blackmails the rich family in order to gain money. The Yasaran family decides to give money to Kerim and forces him to get married with Fatmagul in order to present what had happened as an act between two young persons in love. Fatmagul gets married to Kerim as she is forced by Mukades in order to restore the shameful act.

Gradually, Kerim falls in love with Fatmagul and conducts several acts aiming to prove his love to her. Among these acts he buys a restaurant to Fatmagul so that she starts working and he goes to the police and declares what have happened to her (the fact that the 4 men raped her but precising clearly at the same time that he did not participated actively in the act of rape). So, it is through Kerim that Fatmagul decides to apply a charge against her rapists. At the final episode, she wins the procedure against her rapists and she leaves the court by making a speech against violence towards women after having become a symbol of denunciation of rape (something that is not given in the Turkish society). Fatmagul also had fallen gradually in love with Kerim. After having go through several adventures together they get married again (this time being actually in love) and they live happily ever after.

According to our analysis, this serial contributed to the further establishment of the patriarchate's power under a cover of denunciation of acts of violence towards women. And this, because even if the serial revendicates a feminist position by the condemnation of the three rapists (and presenting this as something that should be applied in every similar incident) it contributes at the same time to the legitimation (at a social level of course) of the act of rape by several means.

First of all, the act of rape is being put under question here. The fact that the protagonist did not participate actively in the rape seems to be an effort to detach his part of responsibility to the crime even though that Kerim caught Fatmagul while she was trying to escape from her rapists, he watched the scene, he did not help her but instead he left her unconscious on the beach. So, on an ethical level (and maybe not on a legal level, at least in the case of Turkey), we could say that Kerim has an equal part of responsibility with the three other men for what have happened to Fatmagul.

In addition, the act of rape was justified due to mitigating circumstances. More precisely, the consumption of drugs and alcohol were presented as the main reasons that conducted the four men to commit the following act (even if later being sober they kept denning their act).

Furthermore, the four men seem to have deeply regretted their act and having remorse for what they did. So, the rape is presented as an ordinary act that anyone can eventually commit. 
As a nonsense that even a young poor but hard working and honest man such as Kerim could have commit. It is like the scenario of this serial is saying to women "don't worry if you are raped, your rapist may be a kind and sensible man that will marry you".

Moreover, it is true that gradually we assist at the emancipation of Fatmagul but this happens in a patriarchic way, which means through Kerim. It is Kerim that buys a restaurant to Fatmagul, so it is because of him that she starts making money of her own. It is Kerim that testifies to the police and denunciates the crime committed against her, it is through him again, that she gets justice. And finally, but most importantly, it is only with him that Fatmagul continues her life. It is Kerim and the woman who raised him, Ebe Nine, that convince Fatmagul to continue her education that she had abandoned years ago and graduate from high school or even to go to a psychologist and speak for what happened to her. Finally, it is Kerim and Ebe Nine that defend Fatmagul against her sister in low Mukades and helps her to escape from the psychological tortures she imposed to her.

So Fatmagul, is supported by him in every step of her life, and what is gained from her (emancipation, justice, education, psychological stability etc.) is presented not only as an individual accomplishment but also as an accomplishment of Kerim.

Of course, the fact that women take pleasure from this serial does not mean that they enjoy watching violence against women or even that they accept the story as it is. We consider that the reception of the representations projected by this serial, by the public in Greece is also important in order to understand how women interpret the relations between men and women and more precisely the violence committed by men towards women.

3. The reception by the public in Greece

During our research, several aspects were pointed out. More precisely, among the 20 persons who had watched the serial 65\% (13 persons) do not consider that Kerim is a rapist or that he has a part of responsibility to what have happened to Fatmagul. Only 7 persons (35\%) consider that Kerim has a responsibility to what have happened to Fatmagul 3 .

However, many of those who agree with the fact that Kerim has his part of responsibility to the rape still do not classify him to the same category with the three other rapists. More precisely, some supported that he "had to do it" (participate to the rape) in order to be socially accepted by his friends and others that the fact that regretted for what he did and stood by the side of Fatmagul distinguishes him from the others. For some persons Kerim is also a victim of the three other men.

In fact, the acts conducted by Kerim in order to prove his love to Fatmagul, made him very likeable to the public. Consequently, Kerim is described by the public as a "correct" man that had all the characteristics that can make a woman to fall in love with him. His patience and his acts made him a hero to the eyes of the public.

However, oppositional decoding is minor but do exist. A 20\% (4 persons) of the population that participated in our research considers inacceptable the fact that Fatmagul gets married with Kerim and declare that they would have preferred a different end.

Thus, quite surprisingly, the big majority of people (16 persons, 80\%) that participated in our research declare that they consider this serial feminist and even revolutionary. The fact that Fatmagul find justice and becomes more dynamic and emancipated (even if she does not do this alone but through Kerim) is for the public the main reason to consider this story feminist 4 .

\footnotetext{
${ }^{3}$ See Annex 3.

4 See Annex 4.
} 


\section{Conclusion}

As each person interpret (decode) the message during the moment of consumption, then it is important not only to analyze the message itself but also the interpretation on behalf of the public. Consequently, for many women this serial defends women's rights and stands against any act of violence towards them. They give to this cultural product a feminist attitude neglecting however that the story is evolving in a patriarchic way ("yes a woman can be emancipated and vindicate her rights but only through a man"). Maybe this neglect is due to the fact that women themselves have interiorize the patriarchic values and maybe they consider them as something natural.

So, under a cover of a superficial feminist ideal this serial subconsciously plays with values and archetypes that contribute to the maintain of the dominant patriarchic society.

However, this does not mean that all women accept its content without questioning. What is important here is to point out the fact that women are critical concerning the cultural product that is proposed to them and they do their own interpretations regarding the serial in question. Either by recognizing the fact that this serial promotes patriarchic values or by considering that the serial in question promotes feminist ideals the important here is that every woman through her interpretation attempts to challenge the patriarchate.

\section{References}

Butler, J. (2006). Défaire le genre. Paris: Éd. Amsterdam.

Cervulle, M., et Quemener, N. (2015). Cultural Studies: Théories et méthodes. Paris: A. Colin.

Duvignaud, J. (1970). Spectacle et Société. Paris: Denoël.

Glevarec, H., Macé, É., et Maigret, É. (2011). Cultural Studies: Anthologie. Paris: A. Colin.

Hall, S. (2008). Le populisme autoritaire. Paris: Éd. Amsterdam.

Hall, S. (2007). Identités et cultures: Politiques des Cultural Studies. Paris: Éd. Amsterdam.

Hoggart, R. (1970). La Culture du pauvre. Étude sur le style de vie des classes populaires en Angleterre. Paris: Minuit.

Kauffmann, J.-C. (1991). La femme seule et le prince charmant. Paris: Pocket.

Lochard, G. et Soulages, J.-C. (1998). La communication télévisuelle. Paris: A. Colin.

Maigret, É. (2003). Sociologie de la Communication et des médias. Paris: A. Colin.

Mattelart, A. et Neveu, É. (2003). Introduction aux Cultural Studies. Paris: La Découverte.

Morin, E. (1956). Le cinéma ou l'homme imaginaire. Paris: Éd. Minuit.

Radway, J. (2000). Lectures à “l'eau de rose”. Femmes, patriarcat et littérature populaire”. Politix 13(51), 163-177.

Silverstone, R. (1990). Télévision, mythe et culture. Réseaux.

Vovou, I. (2009). Les miroirs perforés de la télévision, du gendre étranger aux frontières de l'amour (en grec). Athènes: Hérodote. 
D. L. Larochelle - Theatricalization of Patriarchate' Power ...

Annexes

Annex 1

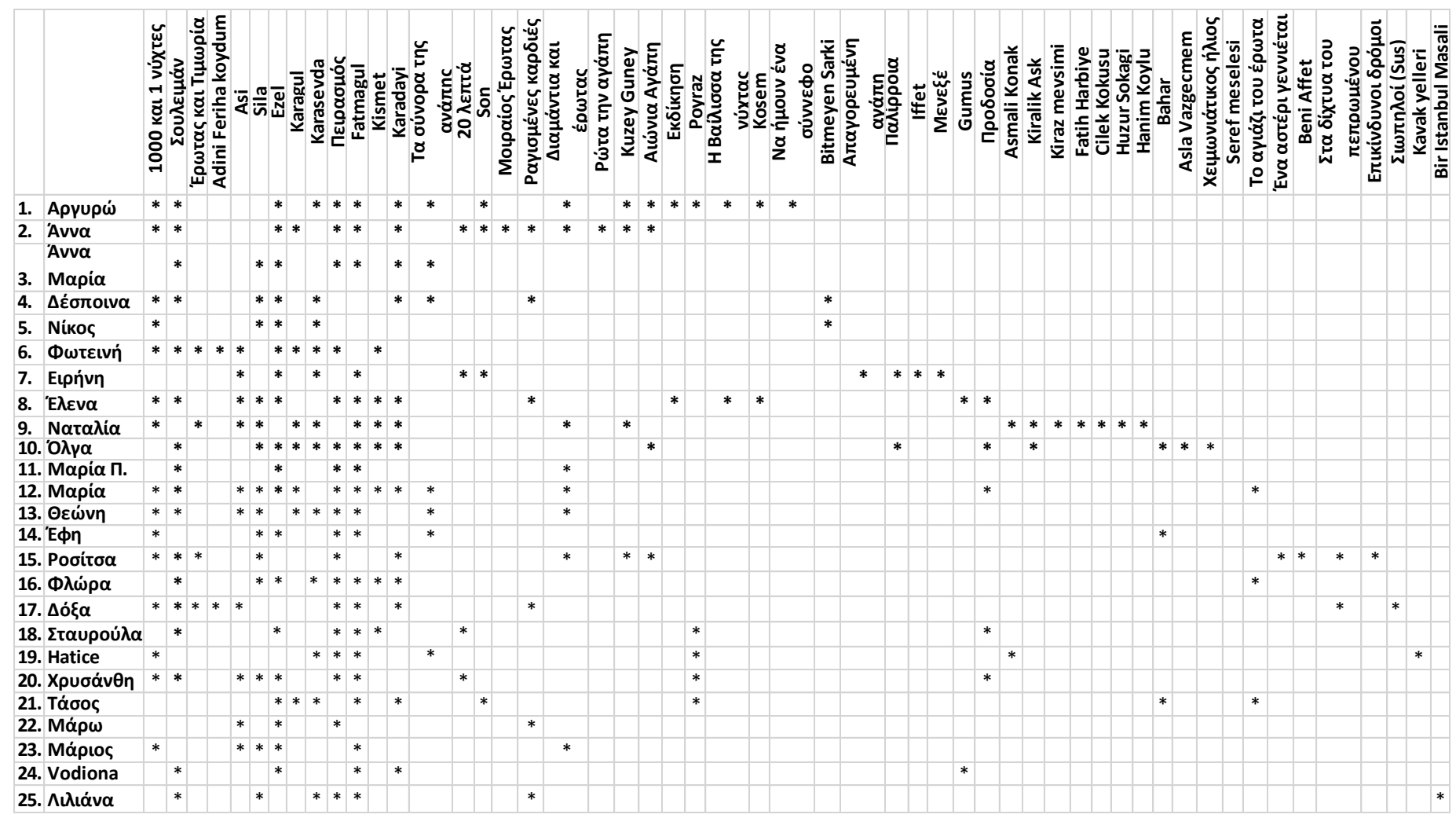

In this table there are presented the frequencies of the viewing of each serial by the public that participated in our research. The vertical column represents the 25 individuals that participated in our research and the horizontal the name of each serial. 


\section{Annex 2}

\begin{tabular}{|c|c|c|c|}
\hline & $\begin{array}{c}\text { Name of the } \\
\text { serial }\end{array}$ & $\begin{array}{c}\text { Number } \\
\text { of } \\
\text { persons }\end{array}$ & $\%$ \\
\hline 1. & $\begin{array}{c}\text { Fatmagul'un } \\
\text { sucu ne? }\end{array}$ & 20 & $80 \%$ \\
\hline 2. & Ezel & 19 & $76 \%$ \\
\hline 3. & 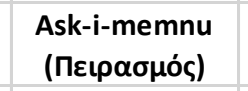 & 18 & $72 \%$ \\
\hline 4. & 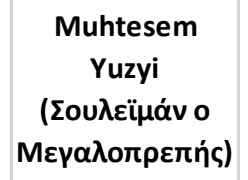 & 17 & $68 \%$ \\
\hline 5. & 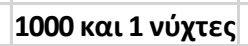 & 16 & $64 \%$ \\
\hline 6. & Sila & 14 & $56 \%$ \\
\hline 7. & Karadayi & 13 & $52 \%$ \\
\hline 8. & Karasevda & 12 & $48 \%$ \\
\hline 9. & Asi & 10 & $40 \%$ \\
\hline 10. & 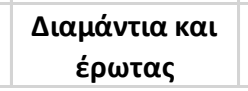 & 8 & $32 \%$ \\
\hline 11. & Karagul & 7 & $28 \%$ \\
\hline 12. & Kismet & 7 & $28 \%$ \\
\hline 13. & 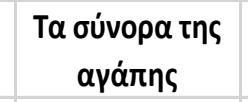 & 7 & $28 \%$ \\
\hline 14. & Paramparca & 6 & $24 \%$ \\
\hline 15. & 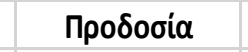 & 5 & $20 \%$ \\
\hline 16. & Poyraz Karayel & 5 & $20 \%$ \\
\hline 16. & Son & 4 & $16 \%$ \\
\hline 17. & $20 \lambda \varepsilon \pi \tau \dot{\alpha}$ & 4 & $16 \%$ \\
\hline 18. & Kuzey Guney & 4 & $16 \%$ \\
\hline 19. & 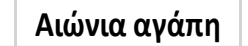 & 4 & $16 \%$ \\
\hline 18. & 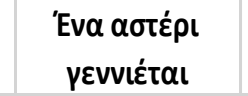 & 4 & $16 \%$ \\
\hline 19. & 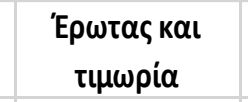 & 4 & $16 \%$ \\
\hline 20. & Bahar & 3 & $12 \%$ \\
\hline 21. & 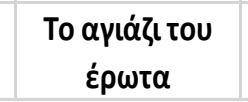 & 3 & $12 \%$ \\
\hline
\end{tabular}

\begin{tabular}{|c|c|c|c|}
\hline 22. & 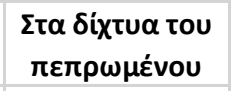 & 2 & $8 \%$ \\
\hline 23. & 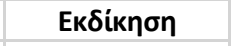 & 2 & $8 \%$ \\
\hline 24. & 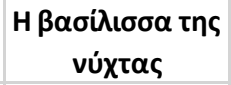 & 2 & $8 \%$ \\
\hline 25. & $\begin{array}{l}\text { Adini Feriha } \\
\text { Koydum }\end{array}$ & 2 & $8 \%$ \\
\hline 26. & Kosem & 2 & $8 \%$ \\
\hline 27. & Bitmeyen Sarki & 2 & $8 \%$ \\
\hline 28. & 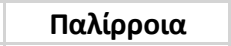 & 2 & $8 \%$ \\
\hline 29. & Gumus & 2 & $8 \%$ \\
\hline 30. & Kiralik ask & 2 & $8 \%$ \\
\hline 31. & Asmali Konak & 2 & $8 \%$ \\
\hline 32. & $\begin{array}{l}\text { Motpaíos } \\
\text { 'Epwtas }\end{array}$ & 1 & $4 \%$ \\
\hline 33. & 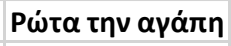 & 1 & $4 \%$ \\
\hline 34. & 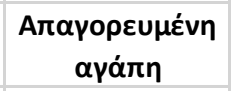 & 1 & $4 \%$ \\
\hline 35. & 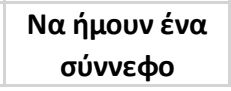 & 1 & $4 \%$ \\
\hline
\end{tabular}

\begin{tabular}{|c|c|c|c|}
\hline 36. & Kiraz mevsimi & 1 & $4 \%$ \\
\hline 37. & Fatih Harbiye & 1 & $4 \%$ \\
\hline 38. & Cilek kokusu & 1 & $4 \%$ \\
\hline 39. & Huzur sokagi & 1 & $4 \%$ \\
\hline 40. & Hanim Koylu & 1 & $4 \%$ \\
\hline 41. & $\begin{array}{c}\text { Asla } \\
\text { Vazgecmem }\end{array}$ & 1 & $4 \%$ \\
\hline 42. & 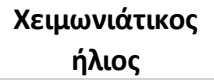 & 1 & $4 \%$ \\
\hline 43. & Seref meselesi & 1 & $4 \%$ \\
\hline 44. & Beni Affet & 1 & $4 \%$ \\
\hline 45. & 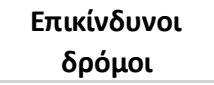 & 1 & $4 \%$ \\
\hline 46. & $\Sigma \iota \omega \pi \iota \lambda o i$ & 1 & $4 \%$ \\
\hline 47. & Kavak yelleri & 1 & $4 \%$ \\
\hline 48. & $\begin{array}{c}\text { Bir Istanbul } \\
\text { Masali }\end{array}$ & 1 & $4 \%$ \\
\hline 49. & Iffet & 1 & $4 \%$ \\
\hline 50. & 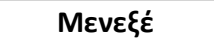 & 1 & $4 \%$ \\
\hline
\end{tabular}

This table presents the distribution of the percentages concerning the viewing of Turkish serials by the public that participated in our research. 
D. L. Larochelle - Theatricalization of Patriarchate' Power ...

\section{Annex 3}

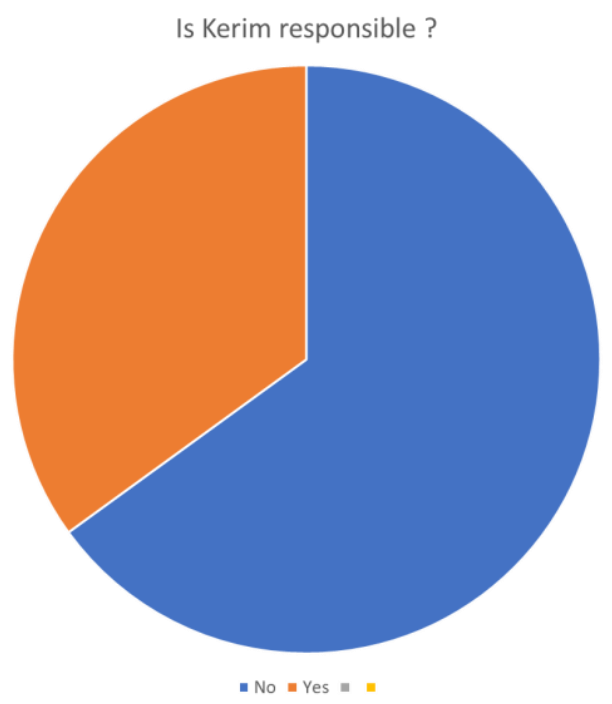

Annex 4

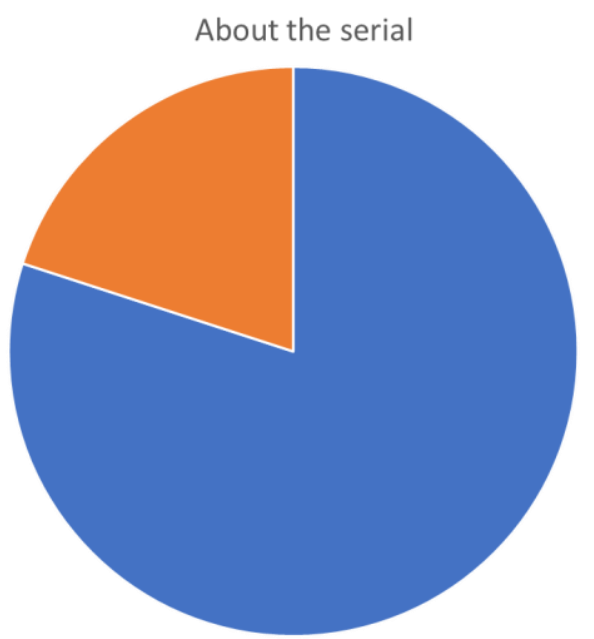

- Feminist serial - It is not OK that she got married with him / I would have preferred a different end 